Pendidikan Penderita Gangguan Jiwa di Pesantren dalam Upaya Menjadikan

Generasi Bangsa Berkarakter

\title{
PENDIDIKAN PENDERITA GANGGUAN JIWA DI PESANTREN DALAM UPAYA MENJADIKAN GENERASI BANGSA BERKARAKTER
}

\author{
Iwan Kuswandi \\ Dosen STKIP PGRI Sumenep \\ kuswandisumenep87@gmail.com
}

\begin{abstract}
This study talks about how is the solving of abnormal person by Kyai Abdurrahman and organizers as therapist in Pesantren Al-Bajigur Tenonan Manding Sumenep Madura? And what are the character education that is used to educating to abnormal person in pesantren? The research is used qualitative approaching by kinds of case study. It is located in Pesantren Al-Bajigur Tenonan Manding Sumenep. The collected method of dates by observation to abnormal person in pesantren, and added by interview deepen to guardian and organizers of pesantren who are therapists to student who has abnormal. The analysis dates is used based on model of Miles $\mathcal{E}$ Huberman. The result of this research are about the method that is used by pesantren Al-Bajigur in handling of abnormal person, namely: First, the family and patient invited to talk persuasively. Second, patient gave thinking and took a bath. Third, patient was gift ingredients meals. Fourth, patient is introduced to environment. And the fifth, patient is prayed as connection of horizontal to the God. And the character education given are self-discipline character, environment care character, independent character, responsibility character, honest character and religious character.
\end{abstract}

The key words: Character Education, Abnormal Person and Pesantren

\begin{abstract}
Abstrak
Tulisan ini mengkaji tentang bagaimana metode penanganan penderita gangguan jiwa oleh Kyai Abdurrahman dan beberapa pengurusnya sebagai terapis di pondok pesantren Al-Bajigur Tenonan Manding Sumenep Madura? Serta apa saja pendidikan karakter yang ditanamkan kepada penderita gangguan jiwa di pesantren tersebut? Penelitian ini menggunakan pendekatan kualitatif dengan jenis studi kasus. Lokasi penelitiannya di pondok pesantren Al-Bajigur Tenonan Manding Sumenep. Metode pengumpulan datanya dengan mengobservasi
\end{abstract}




\section{Iwan Kuswandi}

penderita gangguan jiwa yang ada di pesantren tersebut, dan ditambah dengan wawancara mendalam dengan pengasuh dan pengurus pesantren yang merupakan terapis pada santri penderita gangguan jiwa. Analisis data yang digunakan adalah model Miles \& Huberman. Hasil penelitian ini yaitu tentang metode yang digunakan oleh pesantren Al-Bajigur dalam menangani penderita gangguan jiwa, yaitu: Pertama, keluarga dan pasien diajak berbicara secara persuasif. Kedua, pasien diberi minum dan dimandikan air. Ketiga, pasien diminumkan ramuan jamu. Keempat, pasien dikenalkan dengan lingkungan. Dan yang kelima, pasien didoakan sebagai hubungan horizontal dengan Tuhan. Adapun pendidikan karakter yang diberikan, adalah karakter kedisiplinan diri, karakter peduli lingkungan, karakter mandiri, karakter tanggung jawab, karakter jujur, dan karakter religius.

\section{Kata Kunci: Pendidikan Karakter, Penderita Gangguan Jiwa dan Pesantren}

\section{A. Pendahuluan}

Sampai saat ini, pendidikan yang diselenggarakan pesantren, di hampir seluruh wilayah Indonesia, masih konsisten terhadap pembentukan karakter dan moralitas generasi bangsa, tidak hanya berorientasi pada aspek kognitif semata. Setidaknya, untuk tetap kokoh pada eksistensinya tersebut, maka pesantren senantiasa memegang teguh pada prinsip kaidah fiqh yang populer di kalangan pesantren, al-muhafadhatu a'la al-qadimi as-shalih wa al-akhdu bi al-jadidi al-ashlah. Dalam hal ini, pesantren harus tetap mampu mempertahankan tradisi lama yang baik, dan mengadopsi hal terbaik pada zaman sekarang. Dua tugas tersebut menjadi tanggung jawab seorang kyai sebagai pimpinan dan pengasuh dalam sebuah pesantren.

Pesantren menerapkan totalitas pendidikan dengan mengandalkan keteladanan, penciptaan lingkungan dan pembiasaan melalui berbagai tugas dan kegiatan. Sehingga seluruh apa yang dilihat, didengar, dirasakan dan dikerjakan oleh 


\section{Pendidikan Penderita Gangguan Jiwa di Pesantren dalam Upaya Menjadikan Generasi Bangsa Berkarakter}

santri adalah pendidikan. Selain menjadikan keteladanan sebagai metode pendidikan utama, penciptaan nilai dan karakter juga sangat penting. Pesantren dapat dipandang sebagai institusi yang efektif dalam pembangunan akhlak. Disinilah pesantren mengambil peran untuk menanggulangi persoalan-persoalan tersebut khususnya krisis moral yang sedang melanda. karena pendidikan pesantren merupakan pendidikan yang terkenal dengan pendidikan agama dan seharusnya mampu untuk mencetak generasi-generasi berkarakter yang sarat dengan nilai-nilai Islam (Mas'udi, 2015: 1-13).

Pesantren sebagai sebuah lembaga pendidikan, tentu erat kaitannya dengan nilai-nilai, bahkan pendidikan itu mengandung nilai objektif. Salah satu nilai yang penting dalam pendidikan adalah nilai moral. Kneller dalam Rukiyati, dkk, (2014: 213-224), mengatakan bahwa "Education is widely regarded as a moral enterprise. Teachers are always drawing attention to what ought to be said and done and how students ought to behave. They are concerned with imparting moral values and improving individual and social behavior."

Meskipun aspek religiusitas menjadi platform utama pendidikan pesantren, sesungguhnya pesantren dengan model pendidikan berasramanya juga secara tak langsung bisa mewujudkan suasana belajar dan pendidikan yang mampu membangun kemandirian siswa. Usaha menanamkan karakter atau akhlak terhadap santri di pondok pesantren dilakukan melalui proses pendidikan secara terusmenerus, saling mengisi antara kegiatan tatap muka teoretik-literer dengan praktik 


\section{Iwan Kuswandi}

keseharian santri dalam lingkungan kondusif-aplikatif. Kegiatan keseharian santri tersebut dilakukan dengan penuh kesadaran dan pemahaman. Kemudian dilakukan berulang-ulang setiap harinya sehingga menjadi sebuah habituasi. Prinsip-prinsip pembentukan karakter mandiri yang dikembangkan di Pondok Pesantren umumnya menggunakan pembelajaran berbasis komunitas yang berangkat dari realitas alam dan kehidupan (Ubaidillah, 2016: 1-12).

Pendidikan karakter pada hakikatnya berusaha mewujudkan pendidikan yang mampu membentuk individu menjadi pribadi yang bermoral dan religius. Sikap religius sangat diperlukan untuk menjaga keselarasan kehidupan ini. Membentuk manusia yang beriman dan bertakwa kepada Tuhan Yang Maha Esa dan berakhlak mulia merupakan tujuan yang sangat mendasar dalam pendidikan. Artinya bahwa dari proses pendidikan yang ada, diharapkan akan tercipta generasi bangsa yang religius. Generasi bangsa yang mampu menselaraskan olah rasa, olah hati, olah rasa/karsa, dan olah raga untuk mewujudkan perilaku yang bertakwa kepada Allah SWT, humanis, pluralis, dan demokratis (Wardoyo, 2015: 90-103). Hal tersebut selaras dengan Undang-Undang Republik Indonesia nomor 20 tahun 2003 tentang Sistem Pendidikan Nasional (UU Sisdiknas) yang merumuskan fungsi dan tujuan pendidikan nasional. Pasal 3 UU Sisdiknas menyebutkan, "Pendidikan nasional berfungsi mengembangkan dan membentuk watak serta peradaban bangsa yang bermartabat dalam rangka mencerdaskan kehidupan bangsa, bertujuan untuk berkembangnya potensi peserta didik agar menjadi manusia yang beriman dan 


\section{Pendidikan Penderita Gangguan Jiwa di Pesantren dalam Upaya Menjadikan Generasi Bangsa Berkarakter}

bertakwa kepada Tuhan Yang Maha Esa, berakhlak mulia, sehat, berilmu, cakap, kreatif, mandiri, dan menjadi warga negara yang demokratis serta bertanggung jawab".

Kyai merupakan tokoh sentral di sebuah pesantren. Kyai merupakan sumber inspirasi dan sumber pengetahuan bagi santrinya secara absolut, karena hal inilah kyai bebas menentukan model pesantrennya, sesuai dengan format yang diinginkannya tanpa campur tangan siapa dan pihak manapun. Salah satu kelebihan yang dimiliki oleh seorang kyai di pesantren, dianggap sebagai orang yang memiliki kelebihan di bidang kepemimpinan keilmuan (intellectual leader), hal ini karena seorang kyai dianggap memiliki keahlian ilmu secara mendalam yang dijadikan rujukan atau panutan masyarakat dalam menyelesaikan persoalan. Bidang ilmu itu misalnya ilmu fikih, ilmu hadits dan lain sebagainya.

Namun saat ini, sudah banyak ditemukan pesantren yang memiliki spesialisasi keilmuan tidak hanya di bidang keagamaan ansich, pondok pesantren yang sering dibayangkan hanya berkutat dengan ilmu agama dan kegiatan mengaji Al-Quran serta kitab kuning, dari pagi hingga malam hari. Saat ini, di beberapa pesantren, para santri tidak hanya diajari mengaji ataupun belajar ilmu agama, namun mereka dibina dengan kemampuan usaha dan keterampilan hidup, seperti di sektor pertanian atau agrobisnis, perbengkelan, dan bidang keterampilan lainnya. Selain itu, ada juga beberapa pesantren yang konsentrasi keilmuan dan dakwah kyainya, menjadikan pesantrennya sebagai lembaga yang menangani para penderita 


\section{Iwan Kuswandi}

gangguan jiwa. Sebagaimana di Madura, terdapat pondok pesantren yang khusus menangani orang yang mengalami gangguan jiwa, salah satunya di pesantren AlBajigur, di desa Tenonan Kecamatan Manding Kabupaten Sumenep, provinsi Jawa Timur, Indonesia. Pesantren Al-Bajigur merupakan lembaga pendidikan pesantren yang di dalamnya juga mendidik santri penderita gangguan jiwa. Di pesantren tersebut, walaupun terdapat dari kalangan santrinya dari penderita gangguan jiwa, akan tetapi tetap menjalankan orientasi pesantren pada umumnya, yaitu penanaman karakter kepada para santrinya.

Setiap tempat pengobatan itu, memiliki ciri tersendiri dalam proses penyembuhan pasien yang mengalami gangguan kejiwaan. Proses penyembuhan yang dilakukan itu menurut keyakinan oleh terapis, karena terapislah yang memiliki wewenang sebagi sentral dari proses terapi. Dalam proses terapi yang biasa dilakukan tidak hanya terapis yang melakukan terapi tersebut, pasien pasti dilibatkan dalam proses tersebut. Bahkan dalam metode pengobatan tersebut, kyai Abdurahamn juga menanamkan dan mendidik santri penderita gangguan jiwa, dengan karakter dan nilai pendidikan sebagaimana pesantren pada umumnya. Berangkat dari permasalahan itulah, kemudian menarik untuk dikaji tentang bagaimana metode penanganan penderita gangguan jiwa oleh Kyai Abdurrahman sebagai terapis di pondok pesantren Al-Bajigur Tenonan Manding Sumenep Madura? Serta apa saja pendidikan karakter yang ditanamkan kepada penderita gangguan jiwa di pesantren tersebut? Penelitian ini menggunakan pendekatan kualitatif dengan 


\section{Pendidikan Penderita Gangguan Jiwa di Pesantren dalam Upaya Menjadikan Generasi Bangsa Berkarakter}

jenis studi kasus. Lokasi penelitiannya di pondok pesantren Al-Bajigur Tenonan Manding Sumenep. Metode pengumpulan datanya dengan mengobservasi penderita gangguan jiwa yang ada di pesantren tersebut, dan ditambah dengan wawancara mendalam dengan pengasuh dan pengurus pesantren yang merupakan terapis pada santri penderita gangguan jiwa. Analisis data yang digunakan adalah model Miles \& Huberman.

\section{B. Pembahasan}

\section{Pesantren Al-Bajigur Sebagai Lembaga Bagi Penderita Gangguan Jiwa}

Kyai Abdurrahman mendirikan pesantren Al-Bajigur pada 23 Desember 1995. Dua bulan berikutnya, tepat pada tanggal 26 Februari 1996, pengurus pesantren tersebut bermusyawarah untuk mendirikan yayasan. Lalu pada 28 Februari 1996, surat ijin pendirian yayasan keluar. Sedangkan pesantren Al-Bajigur dikenal sebagai pondok Al-Majnun, berdiri pada tahun 1998. Waktu itu ada warga yang datang kepada Kyai Abdurrahman meminta bantuan agar keluarganya yang stres disembuhkan. Alhamdulilah, sembuh setelah kyai tersebut mengobati pasien tersebut. Sejak itulah, kemudian pesantren yang diasuh oleh Kyai Abdurrahman dikenal sebagai pesantren yang bisa menangani penyembuhan orang gila.

Kyai Abdurrahman lahir hari Jum'at Legi, pada 11 Mei 1958, dari seorang ibu bernama Nyai Nawamu dan ayah Kyai Mubarrun. Sekitar usia 6 tahun beliau diasuh oleh pamannya yang bernama Kyai Samsu'din di Dusun Saasa (sebelah selatan makam Pangeran Jokotole, tokoh dalam sejarah Kerajaan Sumenep). Di desa inilah 


\section{Iwan Kuswandi}

beliau mulai belajar membaca Al-Qur'an pada Kyai Yahya dan Kyai Ishak yang masih saudara sepupu. Sehubungan dengan bapak angkatnya (Kyai Samsu'din) tidak dikaruniai putra, maka tidak heran jika perhatiannya terpusat pada Kyai Abdurrahman. Pada usia 6 tahun itu pula beliau disekolahkan di Sekolah Dasar Negeri (SDN) Giring, yang secara kebetulan sekolah tersebut baru didirikan. Setelah lulus Sekolah Dasar pada tahun 1967, beliau menempuh pendidikannya di pondok pesantren Toros Kebun Agung Sumenep di bawah asuhan Kyai Ismail selama 1 tahun. Kemudian Kyai Abdurrahman berkelana untuk menimba ilmu kepada beberapa Kyai di Jawa dan Madura. Bahkan menurut penuturan beliau, beliau tidak pulang beberapa tahun hanya untuk mengamalkan satu surat dari Al-Qur'an dan untuk mencari barokah dari seorang kyai yang didatanginya.

Pada usia 21 tahun, Kyai Abdurrahman menikah dengan sepupunya, Nyai Rosiliyah Nafiroh yang pada saat itu bernama Nyai Khairosi Bashariyah, putri dari Kyai Abdullah bin Amiruddin. Dari perkawinan inilah, dikaruniai tujuh anak putraputri. Salah seorang putranya yang juga merupakan anak sulungnya, Kyai Masturrahman Abdi. Dialah yang kemudian banyak membantu dalam pengelolaan dan pengembangan pesantren Al-Bajigur. Saat ini putranya inilah, yang menjadi Ketua Yayasan pesantren tersebut, dan menjadi salah seorang yang membantu dalam penanganan atas penyembuhan penderita gangguan jiwa yang ada di pesantren tersebut. 


\section{Pendidikan Penderita Gangguan Jiwa di Pesantren dalam Upaya Menjadikan Generasi Bangsa Berkarakter}

Sebenarnya di pesantren Al-Bajigur ini, bukan hanya menampung santri yang mengalami gangguan jiwa, akan tetapi juga terdapat santri normal sebagaimana pesantren pada umumnya. Hanya yang berbeda, khusus bagi santri yang mengalami gangguan jiwa dan tergolong emosinya masih tinggi atau sering mengamuk dan memukul, mereka ditempatkan di pondok gedek (terbuat dari bambu) dan ada yang ditempatkan di kamar khusus. Saat ini, pesantren Al-Bajigur sudah membuka jenjang pendidikan formal, dari Madrasah Ibtidaiyah Nurul Bani, Sekolah Menengah Pertama Plus, serta Sekolah Menengah Atas Nurul Bani. Secara kurikulum kepesantrenan, pesantren Al-Bajigur menerapkan kurikulum salaf, tentunya di dalamnya mengajarkan kitab-kitab sebagaimana di pesantren salaf (tradisional) di Indonesia, seperti kitab untuk bidang fiqih mengajarkan Safinatun Najah dan Taqrib, untuk ilmu alat Bahasa Arab memakai kitab al-Jurmiyah sampai Alfiyah, dan beberapa kitab lainnya.

Sebelum membahas tentang metode penanganan penderita gangguan jiwa di pesantren Al-Bajigur. Ada baiknya terlebih dahulu tentang jenis orang yang ada di pesantren Al-Bajigur. Menurut Kyai Masturrahman (2017), Ketua Yayasan pesantren Al-Bajigur, bahwa yang ada di pesantrennya, adakalanya orang yang datang untuk minta direhabilitasi, mereka bukan karena tergolong sebagai orang gila, namun juga banyak dikarenakan stres, sehingga perlu untuk ditempatkan di pesantren tersebut. Pertama, bisa nampak dengan bertingkah aneh dan tidak kenal dengan diri sendiri. Kedua, ada juga orang yang selalu dan sering berteriak sendiri, bahkan juga ada 


\section{Iwan Kuswandi}

orang yang suka memukul diri sendiri. Dan yang ketiga, ada orang yang datang karena takut pada api. Dan golongan keempat, ada orang sering tidak tidur sampai larut malam. Di samping itu, ada juga santri penderita gangguan jiwa yang diasuh di pesantren Al-Bajigur karena kesurupan. Pada tahun 2017, menurut Kyai Masturrahman menjelaskan bahwa jumlah santri di pesantren tersebut yang mengalami gangguan jiwa, berjumlah sekitar 50an orang.

Sebagai contoh, jenis gangguan jiwa yang banyak ditangani di pesantren AlBajigur adalah Skizophrenia. Skizophrenia berasal dari kata shizo, berarti "jiwa" dan phren yang berarti "kacau". Kalau digabung, skizophrenia berarti "jiwa yang terbelah" atau split of personality, karena penyakit ini memang menyebabkan penderita seolah-olah punya jiwa yang lain (Akhmad, 2013a: 17). Menurut Suryani dalam Suhaimi (2015: 199-200), bahwa salah satu faktor gangguan jiwa Skizophrenia, karena faktor biologik. Untuk membuktikan bahwa gangguan jiwa adalah suatu penyakit biologik atau keturunan ataupun ginetik penelitian membuktikan bila salah satu orang tua mengalami skizofrenia kemungkinan 15\% anakanya mengalami skizofrenia. Sementara bila kedua orang tua menderita maka 35-68\% anaknya akan menderita skizofrenia, dan kemungkinan skizofrenia meningkat apabila orang tua, anak dan saudara kandung menderita skizofrenia. Pendapat ini didukung oleh Slater yang menyatakan pevalansi skizofrenia lebih tinggi pada anggota keluarga yang individunya sakit dibandingkan dengan prevalansi penduduk umumnya. Di pesantren Al-Bajigur, faktor penyebab gangguan jiwa skizofrenia, sebagian besar 


\section{Pendidikan Penderita Gangguan Jiwa di Pesantren dalam Upaya Menjadikan Generasi Bangsa Berkarakter}

disebabkan oleh Narkoba, walaupun ada juga yang disebabkan oleh keluarga, ekonomi, ilmu, cinta, trafficking, Putus Hubungan Kerja (PHK), dan faktor genetik.

Menurut Kyai Masturrahman yang merupakan pengurus yayasan sekaligus sebagai terapis yang menangani pasien gangguan jiwa menjelaskan bahwa problematika gangguan jiwa yang dialami oleh pasien sebenaranya bervariasi entah yang bersifat stress, kesurupan, gangguan mental, dan gila. Untuk kasus stres, ada yang stres karena permasalahan rumah tangga. Selain itu, ada juga pasien yang kesurupan sehingga menjadi mengalami gangguan jiwa karena tidak kuat dengan amalan ilmu yang tidak sepantasnya diamalkan oleh anak muda, ini banyak terjadi dari kalangan santri yang sedang nyantri di sebuah pesantren. Kalau pasien yang mengalami gangguan jiwa di kalangan mahasiswa, kebanyakan karena mereka sebagai pecandu narkoba. Beliau menambahkan bahwa santri penderita gangguan jiwa di pondok tersebut kadangkala mengalami musiman. Biasanya paling banyak ketika saat selesai pemilihan kepala desa, bupati, gubernur dan lain sebagainya.

\section{Metode Penanganan Penderita Gangguan Jiwa di Pesantren}

Metode atau tahapan yang digunakan dalam proses penanganan pasien gangguan jiwa di pesantren Al-Bajigur. Menurut Kyai Abdurrahman (2017), selaku pengasuh pesantren tersebut, ada beberapa tahapan dalam penanganan pasien gangguan jiwa, yaitu: Pertama, pasien yang datang akan dilihat dari seberapa ringan dan beratnya gangguan yang ia alami dengan cara diajak berbicara secara persuasif, kedua pasien dimandikan dengan seorang terapis yang menangani, ketiga pasien 


\section{Iwan Kuswandi}

diminumkan ramuan jamu yang sudah diracik oleh terapis yang akan menaganinya, keempat dikenalkan dengan lingkungan, termasuk tempat dan teman yang sedang menjalani proses reahabilitasi serta mengajarkan untuk bercocok tanam di area sekitar pondok pesantren tersebut, kelima pasien didoakan sebagai hubungan horizontal dengan Tuhan. Penanganan tidak dilakukan setiap hari namun dilakukan tiga kali dalam seminggu selebihnya mereka dipantau dari sosial lingkungan dan proses kedekatan dengan Allah SWT tentunya melalui proses ibadah ubudiah dan muamalah.

Pada langkah pertama, Kyai Abdurrahman melakukan wawancara dengan keluarga penderita gangguan jiwa, hal ini untuk mengetahui tentang penyebab terjadinya gangguan jiwa tersebut. Namun cerita dari keluarga, tidak langsung membuat yakin kyai dan para pengurus. Untuk selanjutnya dilakukan pendekatan dan pembicaraan persuasif terhadap pasien atau klien tersebut. Tentu hal ini, untuk bisa memberikan penanganan apa yang tepat untuk penderita gangguan jiwa tersebut.

Langkah pendahuluan yang dilakukan oleh Kyai Abdurrahman di pesantrennya tersebut, dalam menangani penderita gangguan jiwa, merupakan bagian dari upaya pemeriksaan awal. Kalau kemudian dibandingkan dengan teori sistem neuropsikiatri, dikenal sebagai pemeriksaan status mental. Sebagaimana diuraikan dalam Buku Panduan Mahasiswa Tehnik Keterampilan Pemeriksaan Status Mental, Skill Lab. Sistem Neuropsikiatri Fakultas Kedokteran Universitas Hasanuddin 


\section{Pendidikan Penderita Gangguan Jiwa di Pesantren dalam Upaya Menjadikan Generasi Bangsa Berkarakter}

Makassar 2015, dijelaskan bahwa pemeriksaan status mental meliputi penilaian status mental, penilaian kesadaran, penilaian aktivitas psikomotorik, penilaian orientasi, penilaian persepsi, penilaian bentuk dan isi pikir, penilaian mood dan afek, penilaian pengendalian impuls, penilaian menilai realitas, penilaian kemampuan tilikan (insight), penilaian kemampuan fungsional.

Setelah selesai pada langkah pertama, kemudian berlanjut pada langkah kedua, santri penderita gangguan jiwa tersebut terlebih dahulu diberi air putih, lalu dimandikan. Pemberian air ini biasanya dilakukan oleh Kyai Abdurrahman pada hari pertama, pada saat pasien baru sampai di pesantrennya. Dalam proses penyembuhan hari pertama, santri yang sakit terlebih dahulu diberi air putih. Pada malam harinya, ratusan santri yang normal membaca shalawat Qasidah Burdah karangan Imam alBusiri, dikhususkan ke para santri yang gila tersebut. Tepat tengah malam, mereka dimandikan air putih dengan dicampur air kelapa hijau seraya didoakan doa tolak bala' untuk kesembuhannya. Selain itu, setiap malam Jum'at, dari setelah Shalat Maghrib sampai pelaksanaan Shalat Isya', diadakan istighatsah yang diikuti oleh santri yang normal. Ditambah lagi, dengan diadakan secara rutin bulanan, setiap malam Jum’at Legi dengan diadakannya doa bersama.

Pembacaan Qasidah Burdah bagi orang sakit, tentu di dunia santri dan masyarakat Islam di Indonesia, sudah banyak dilakukan karena diyakini oleh sebagian besar mereka, bahwa bacaan tersebut akan menjadi wasilah untuk mendapat kesembuhan. Hal ini dilakukan karena selaras dengan makna yang 


\section{Iwan Kuswandi}

dikandung dari kata Burdah, yang memiliki arti mantel dan juga dikenal sebagai bur'ah yang berarti shifa' (kesembuhan). Di samping itu, berdasarkan cerita pengarang Qasidah Burdah, Imam Bushiri sendiri. Konon ketika ia sedang menderita kelumpuhan akibat penyakit yang bernama angin merah, dalam mimpinya ia bertemu dengan Rasulullah SAW dan kemudian Rasulullah memberikan mantel (burdah) itu kepadanya. Yakni mantel yang sama seperti yang diberikan Ka'ab, ia terkejut dan melompat dari tidurnya sehingga lumpuhnya tak terasa lagi. Begitu bangun ia merasa terharu sekali lalu menulis syair-syair yang dikenal dengan judul al-kawakib ad durriyah (bintang-bintang gemerlapan). Syair tersebut berisi puji-pujian terhadap Nabi Muhammad SAW. Dan karena ada hubungannya dengan mantel yang diberikan oleh Nabi, maka kemudian syair-syair tersebut dikenal dengan nama alBurdah. Burdah terdiri dari 160 bait, yang berisi nasihat dan peringatan; umpamanya soal angkara nafsu, pujian kepada Nabi, keagungan Al-Quran, Isra Miraj, jihad prajurit Nabi Muhammad SAW, doa-doa (munajat-munajat) serta shalawat kepada Nabi, keluarga, para sahabat (Setiawan, 2015: 1-8).

Berkenaan dengan terapi air yang diberikan kepada santri penderita gangguan jiwa, menurut Kyai Masturrahman (putra Kyai Abdurrahman), apabila ada orang yang mengalami gangguan jiwa tersebut perlu direndam di air dengan lama waktu kurang lebih sekitar 2 - 4 jam di sungai dekat Pondok Pesantren Al-Bajigur, sehingga ketika penderita merasa kedinginan sampai menggigil, maka secara tidak langsung ia membberikan sinyal akan segera sembuh. Hal senada diutarakan oleh Kyai 


\section{Pendidikan Penderita Gangguan Jiwa di Pesantren dalam Upaya Menjadikan Generasi Bangsa Berkarakter}

Abdurrahman, khusus pasien yang masih mudah mengamuk, maka terapi yang diberikan direndam di air terlebih dahulu. Khusus nntuk pecandu narkoba, selain tidak boleh meminum obat apapun selama proses penyembuhan di pesantren tersebut, mereka akan lebih sering direndam di air.

Proses pemandian dengan air tersebut bertujuan untuk menghilangkan kekuatan jin yang seringkali memunculkan emosi tidak terkendali, santri yang mengalami gangguan jiwa juga dipijat refleksi. Para santri yang sakit ini setiap hari harus mengikuti pijat refleksi urat syaraf, yang bertujuan untuk mengembalikan sel-sel yang rusak bagi para pecandu narkoba, yang kemudian mereka disuruh untuk minum air putih yang sudah disediakan oleh pengasuh, serta diberikan juga pendekatan kejiwaan melalui komunikasi kasih sayang dari pengasuh dan perawat. Tujuannya, untuk menetralisir penyakit jiwa yang sudah lama bersarang dan menghilangkan tekanan jiwa mereka.

Tentu dalam banyak hal, pijat refleksi tidak hanya dapat mengembalikan sel-sel pada urat saraf sebagaimana diyakini oleh Kyai Abdurrahman di pesantren AlBajigur. Ternyata, pijat refleksi memberikan hasil positif terhadap penurunan tekanan darah yang dimiliki oleh seseorang. Sebagaimana hasil penelitian eksperimen Sri Hartutik dan Kanthi Suratih, hasilnya bahwa tekanan darah sesudah dilakukan terapi pijat refleksi kaki pada kelompok perlakuan dan kelompok kontrol. Tekanan darah sesudah perlakuan, yaitu dengan menggunakan terapi pijat refleksi kaki pada kelompok perlakuan mengalami penurunan tekanan darah yang 


\section{Iwan Kuswandi}

signifikan. Pada kondisi awal dengan ratarata 154,6/94,1 mmHg menurun menjadi 128,6/80,0 mmHg. Sedangkan pada kelompok kontrol 153,6/94,5 mmHg hanya turun sedikit menjadi menjadi 152,3/92,3 mmHg. Hal ini menggambarkan pada kelompok yang diberikan terapi pijat refleksi kaki mengalami penurunan yang cukup tajam dibandingkan dengan kelompok kontrol. Pada kelompok yang diberikan terapi pijat refleksi kaki mengalami penurunan yang lebih tajam dibandingkan dengan kelompok yang tidak diberikan terapi. Setelah diberikan terapi pijat kaki dari hipertensi tingkat 1 rata-rata turun menjadi pre hipertensi dan ada 2 responden yang normal. Sedangkan pada kelompok kontrol dari hipertensi tingkat satu setelah pengukuran akhir tetap hipertensi tingkat I. Hasil penelitian tersebut menunjukkan efektivitas penurunan tekanan darah yang cukup signifikan akibat diberikan diberikan terapi pijat kaki (Hartutik \& Suratih, 2017: 132-146).

Membahas tentang hubungan doa dengan air. Doa yang dibacakan oleh Kyai Abdurrahman terhadap air yang akan diminumkan dan dimandikan kepada para penderita gangguan jiwa, tentu hal itu, sangat memberikan kontribusi positif terhadap kesembuhan penderita gangguan jiwa yang ada di pesantren Al-Bajigur. Hal ini senada dengan hasil penelitian Dr. Masaru Emoto dari Universitas Yokohama Jepang, ia dengan tekun melakukan penelitian tentang perilaku air. Pada saat diundang ke Markas Besar PBB di New York untuk mempresentasikan temuannya pada bulan Maret 2005 lalu. Ternyata air bisa "mendengar" kata-kata, bisa "membaca" tulisan, dan bisa "mengerti" pesan. Hasil penelitian tersebut kemudian 


\section{Pendidikan Penderita Gangguan Jiwa di Pesantren dalam Upaya Menjadikan Generasi Bangsa Berkarakter}

diterbitkan menjadi sebuah buku. Dalam bukunya, Dr. Masaru Emoto menguraikan bahwa air bersifat bisa merekam pesan, seperti pita magnetik atau compact disk. Dalam hal ini, air membawa pikiran dan doa kita. Bahkan dunia dan air kita dapat diubah dengan doa yang dibacakan (Emoto, 2006: 87-109).

Pada langkah ketiga dalam penanganan pasien penderita gangguan jiwa, santri yang bersangkutan disuruh untuk meminum jamu yang diracik oleh kyai dan pengurus di pesantren Al-Bajigur. Para santri yang mengalami gangguan jiwa diberi minuman jamu tradisional. Asumsi Kyai Abdurrahman bahwa para penderita gangguan jiwa akan sembuh dalam waktu sekitar 4 bulan. Dalam rentan waktu tersebut, maka pemberian obat tradisional yang diambil dari tumbuh-tumbuhan, juga menggunakan binatang yang dianggap mampu menyembuhkan penyakit yang memang sulit disembuhkan. Seperti sarang laba-laba yang mampu meringankan rasa pusing di kepala dan sebagainya. Sebab rata-rata orang yang kehilangan akal sehatnya, biasanya memang diawali rasa pusing di kepala.

Sebenarnya, akhir-akhir ini sudah banyak para peneliti dan ilmuwan yang menemukan tentang manfaat sarang laba-laba. Sebagai bukti, para ahli Farmakologi di Universitas Wyoming Amerika Serikat memanfaatkan benang laba-laba Nephila sebagai benang jahit untuk operasi yang sangat sensitif, seperti: operasi-operasi pada tendon, operasi mata, atau jaringan syaraf. Ditambah lagi, para ilmuwan di Inggris telah menemukan cara untuk membuat jaring laba-laba sintetis yang sarat dengan 


\section{Iwan Kuswandi}

sifat antibiotik, dan bisa membantu memberikan obat serta menutup luka terbuka dengan penurunan risiko infeksi.

Dan yang terbaru, pada tahun 2014, sebagaimana ditulis oleh Ika yang berjudul, “Spidweb Gel, Jaring Laba-laba Percepat Penyembuhan Luka Cabut Gigi (2014), dalam tulisannya dijelaskan bahwa ada empat mahasiswa Fakultas Kedokteran Gigi Universitas Gajah Mada, Yogyakarta Indonesia, mereka itu adalah Effendi Halim bersama Mirna Aulia, Claudia Twistasari, Choirunisa Nur Humairo, dan Bayu Anggoro Aji, yang mengembangkan obat bernama Spidweb Gel ini. Pengembangan obat ini berawal dari keperihatinan mereka akan tingginya jumlah penderita karies dan penyakit periodonatal, sementara kesadaran masyarakat untuk melakukan perawatan gigi rendah sehingga menyebabkan tingginya kasus pencabutan gigi. Sementara penyembuhan luka pada soket setelah pencabutan gigi dalam beberapa kasus tertentu menyebabkan perlambatan proses penyembuhan luka. Mereka berempat, saat ini sedang mengembangkan obat bernama Spidweb Gel yang terbuat dari sarang laba-laba, obat ini digunakan untuk pemulihan luka pasca operasi cabut gigi.

Langkah keempat pada penanganan penderita gangguan jiwa, dengan dikenalkan pada alam dan lingkungan sekitar, yaitu dengan diberi aktivitas dan dilatih mandiri berupa prakarya sosial (Dzulkarnain, dkk, 2016: 215-222). Sedangkan pada langkah kelima dan merupakan kunci utama yang diyakini oleh Kyai Abdurrahman dalam mengobati orang yang mengalami gangguan jiwa, yaitu dengan taqarrub kepada 


\section{Pendidikan Penderita Gangguan Jiwa di Pesantren dalam Upaya Menjadikan Generasi Bangsa Berkarakter}

Allah dan selalu mendoakan mereka, setiap selepas shalat fardhu dan shalat sunnah. Tidak hanya Kyai Abdurrahman, pengurus dan santri normal yang memanjatkan doa. Akan tetapi, pesantren tersebut melakukan upaya rehabilitasi penyakit gangguan jiwa dengan cara ibadah, seperti zikir, salat, dan membaca atau mendengarkan bacaan Al-qur'an. Metode penanganan lain juga bagi pasien yang mengalami gangguan jiwa di pondok ini salah satunya menggunakan metode ruqyah syar'iyyah. Dimana ruqyah ini salah satu warisan pengobatan yang datang dari rasulullah dalam menyembuhkan berbagai macam penyakit atas izin dan kehendak Allah tentunya dalam penerapannya tak lepas dari nilai-nilai Al-Qur'an dan AsSunnah.

Menurut Perdana Akhmad terapi ruqyah memiliki banyak keistimewaan yaitu bisa kita gunakan untuk mengobati seorang yang menderita penyakit fisik, psikis baik secara medis maupun karena gangguan jin dan serangan sihir serta gangguan mental kejiwaan salah satunya dengan bacaan doa kedalam air (Akhmad, 2013b: 12). Ruqyah merupakan salah satu cara pengobatan terhadap penyakit, baik penyakit fisik maupun non fisik yang telah ada sebelum datangnya Islam (Adynata, 2013: 77).

Ruqyah adalah suatu terapi penyembuhan dari penyakit fisik, non fisik atau psikis dengan Ayat-ayat Al-Qur'an dan doa.Ruqyah dalam bahasa Arab jika diartikan dalam bahasa Indonesia berarti Jampi atau mantra. Jampi-jampi atau mantera sudah lama di amalkan oleh manusia sebelum kedatangan Islam dan ia mengandungi kata-kata yang tidak dimengerti, atau memuja dan menyeru 


\section{Iwan Kuswandi}

pertolongan kepada selain Allah sebagai sarana bagi penyembuhan suatu penyakit yang sedang diderita.Setelah kedatangan Islam maka Rasulullah telah mengganti jampi berupa ayat-ayat Al-Qur'an, Asma Allah serta doa-doa tertentu (Akhmad, 2013c: 146).

Ruqyah secara bahasa artinya bacaan. Kalau ada orang yang mengaku bahwa pengobatannya adalah ruqyah tapi dalam praktiknya dia tidak membaca sesuatu, berarti orang tersebut tidak paham sama sekali akan makna ruqyah. Karena bacaan adalah termasuk unsur pokok dalam melakukan praktik ruqyah sesuai dengan definisinya. Bukan ruqyah kalau dalam praktiknya dia tidak membaca sesuatu, walaupun dalam kenyataannya jin yang ada dalam tubuh seseorang keluar atau penyakit yang dideritanya sembuh. Dan bacaan ini bukan baca dengan hati atau tidak bersuara sama sekali. Seorang peruqyah harus membaca bacaan itu dengan bersuara, sehingga isteri, keluarga atau sahabat-sahabatnya mendengar materi bacaannya lalu meriwayatkan kepada yang lain (Akhmad, 2013b: 15-16).

\section{Upaya Menjadikan Generasi Bangsa Berkarakter}

Pada langkah keempat sebagaimana dijelaskan di atas, adalah berbentuk pengenalan dengan lingkungan, titik tekannya pada kedisiplinan diri, seperti kedisiplinan dalam memotong kayu, menyapu, dan membantu tukang kuli bangunan, lebih-lebih kedisiplinan dalam hal pelaksanaan shalat fardhu dan mengaji al-Qur'an. Disiplin merupakan salah satu karakter yang sangat ditekankan di pesantren Al-Bajigur. Sebagaimana pengertiannya bahwa disiplin merupakan 


\section{Pendidikan Penderita Gangguan Jiwa di Pesantren dalam Upaya Menjadikan}

Generasi Bangsa Berkarakter

tindakan yang menunjukkan perilaku tertib dan patuh kepada berbagai ketentuan dan aturan (Narwanti, 2011: 29). Upaya yang dapat dilakukan untuk menumbuhkan kedisiplinan melakukan pembiasaan atau latihan, memberikan contoh, memberikan pemahaman, dan mengontrol. Dengan demikian kedisiplinan yang terbentuk akan menjadi karakter pada diri seseorang (Yasin, 2011: 123-138).

Selain untuk menumbuhkan karakter disiplin, dalam penugasan lingkungan tersebut, ingin menjadikan para santri penderita gangguan jiwa agar cinta pada lingkungan. Kepedulian lingkungan hidup merupakan wujud sikap mental individu yang direfleksikan dalam perilakunya. Sikap mental dan perilaku dapat disebut dengan karakter. Karakter dapat diartikan sebagai watak, tabiat, akhlak dan kepribadian seseorang yang terbentuk dari hasil internalisasi berbagai kebajikan (virtues) yang digunakan sebagai landasan cara pandang berfikir dan, bersikap, dan bertindak. Karakter peduli lingkungan bukanlah sepenuhnya talenta maupun instink bawaan, akan tetapi juga merupakan hasil dari suatu proses pendidikan dalam arti luas. Salah asuh atau salah didik terhadap seorang individu bisa jadi akan menghasilkan karakter yang kurang terpuji terhadap lingkungan. Karena itu, karakter yang baik haruslah dibentuk kepada setiap individu, sehingga setiap individu dapat menjiwai setiap tindakan dan perilakunya (Al-Anwari, 2014: 227-252).

Pemberian tugas berupa prakarya sosial dan lingkungan, menjadi terapi tersendiri bagi penderita gangguan jiwa, agar mereka melakukan anekaragam aktivitas. Dengan banyak gerak, terapi ini, menurut Kyai Abdurrahman, penting 


\section{Iwan Kuswandi}

karena bertujuan agar mereka bisa kembali ke kehidupan normal. "Dengan bebas berkegiatan, otot saraf mereka menjadi tidak kaku, sehingga tidak gampang stres," katanya. Pendekatan lingkungan tersebut sebenarnya bertujuan untuk menguatkan otot-otot mereka yang kaku, juga menguatkan urat syaraf agar tidak mudah depresi. Sebab, ketika mereka beraktivitas sebagaimana mestinya, gairah hidup akan tumbuh dan secara pelahan dia akan bisa melakukan interaksi sosial dengan lingkungan sekitar.

Terapi berbasis prakarya itulah, yang nantinya akan menjadi keterampilan hidup bagi mereka setelah kembali ke keluarga dan masyarakatnya. Sehingga pekerjaan barunya yakni prakarya sosialnya diantaranya ada yang bertani, ada juga yang ikut jadi kuli bangunan, ada juga yang mendapat tugas untuk buat kerajinan tangan. Beberapa dari hasil prakarya sosial tersebut, kemudian dijual dan hasilnya untuk membantu membiayai kehidupan para santri yang menderita gangguan jiwa. Dengan keterampilan yang dimiliki oleh santri yang memiliki pengalaman hidup sebagai penderita gangguan jiwa, tentu dengan keterampilan tersebut akan menjadi modal hidup mereka di masyarakat, akan menjadi insan mandiri. Sebagaimana dikatahui bersama bahwa kemandirian diartikan sebagai self standing yaitu kemampuan berdiri di atas kaki sendiri dengan kemampuan sendiri dan tanggung jawab atas segala tingkah laku sebagai manusia dewasa dalam melaksanakan segala macam kewajiban guna memenuhi kebutuhan sendiri. Seseorang yang telah mampu mengurus dan mengolah dirinya sendiri, memimpin dirinya sendiri, mampu 


\section{Pendidikan Penderita Gangguan Jiwa di Pesantren dalam Upaya Menjadikan Generasi Bangsa Berkarakter}

memenuhi segala kebutuhan pribadinya yang berasal dari berbagai macam kemampuan dalam dirinya, maka ia dapat dikatakan sebagai seorang yang mandiri (Lutviyanti, 2013: 1-14).

Di pesantren juga ditekankan kepada pendidikan life skill. Kehidupan anak penuh dengan dinamika sesuai dengan perkembangan jiwanya. Pendidikan kecakapan hidup (life skill) untuk anak-anak akan menjadi tidak berarti manakala bernuansa paksaan dengan pilihan-pilihan yang sempit karena sudah ditentukan. Yang paling penting adalah mendorong anak untuk terus mencoba dan berkarya sesuai dengan pilihan keinginannya sehingga imajinasi anak bisa luas. Semangat mencoba dan berkarya inilah yang akan membawa siswa menjadi matang dan terampil dalam hidupnya (Ubaidillah, 2016: 1-12).

Selain itu, terapi dengan lingkungan dan hasta karya sosial tersebut, menurut salah seorang pengurus, bahwa untuk melihat perkembangan kesehatan jiwa pasien, maka diberikan terapi tingkah laku, misalnya mengajarkan mereka melakukan pekerjaan tertentu, seperti membersihkan lingkungan pondok dan bercocok tanam, yang tujuannya agar pasien melatih tanggung jawabnya. Sebagaimana arti tanggung jawab yang memiliki makna sikap dan perilaku seseorang untuk melaksanakan tugas dan kewajibannya, yang seharusnya dia lakukan, terhadap diri sendiri, masyarakat, lingkungan (alam, sosial, dan budaya), negara dan Tuhan Yang Maha Esa (Rahayu, 2016: 97-103). 


\section{Iwan Kuswandi}

Salah satu nilai yang menonjol di pesantren adalah tanggung jawab, baik terhadap diri sendiri, lingkungan, orang tua, masyarakat, bangsa dan negara. Para kyai/nyai dan ustadz/ustadzah bertanggung jawab memberikan pendidikan keagamaan kepda para santri, baik melalui kajian kitab maupun teladan nyata. Sementara para santri bertanggung jawab untuk belajar dan mengaji secara sungguhsungguh serta mengamalkan ilmu yang diperolehnya dalam kehidupan (Octavia, 2014: 188).

Selain itu, menurut Kyai Abdurrahman, untuk menguji kesembuhan pasien penderita gangguan jiwa, yaitu dengan dites kejujurannya, misalnya disuruh untuk belanja ke toko Air yang diberikan terlebih dahulu didoakan oleh Kyai Abdurrahman. Jujur adalah perilaku yang dilaksanakan dalam upaya menjadikan dirinya sebagai orang yang selalu dapat dipercaya dalam perkataan, tindakan dan pekerjaan (Narwanti, 2011: 29). Tujuan utama sebuah pendidikan adalah membentuk kejujuran, sebab kejujuran adalah modal dasar dalam kehidupan bersama dan kunci menuju keberhasilan. Melalui kejujuran kita dapat mempelajari, memahami, dan mengerti tentang keseimbangan-keharmonisan. Jujur terhadap peran pribadi, jujur terhadap hak dan tanggung jawab, jujur terhadap tatanan yang ada, jujur dalam berfikir, bersikap, dan bertindak. Nilai kejujuran yang dilandasi oleh nilai-nilai religius, paralel dengan nilai-nilai etika moral yang berlaku secara umum. Pengembangan nilai-nilai bijak tersebut diyakini sangat efektif melalui pendidikan dan hasilnya akan tercermin dalam kehidupan masyarakat. Ini merupakan cita-cita 


\section{Pendidikan Penderita Gangguan Jiwa di Pesantren dalam Upaya Menjadikan Generasi Bangsa Berkarakter}

ideal dari dunia pendidikan sebagai basis untuk belajar kejujuran. Proses penanaman nilai-nilai kejujuran pada anak didik sesungguhnya tidak bisa diajarkan secara teoritis, seperti hafalan definisi atau pendapat para ahli. Penanaman nilai-nilai kejujuran menuntut tata kehidupan sosial yang merealisasikan nilai-nilai tersebut (Emosda, 2011: 151-166).

Dalam pendidikan karakter, anak didik memang sengaja dibangun karakternya agar mempunyai nilai-nilai kebaikan sekaligus mempraktikkannya dalam kehidupan sehari-hari, baik itu kepada Tuhan Yang Maha Esa, dirinya sendiri, sesama manusia, lingkungan sekitar, bangsa, negara maupun hubungan internasional sebagai sesama penduduk dunia (Siswanto, 2013: 91-107). Niali kejujuran menjadi inti dari pendidikan di manapu, jujur terhadap dirinya sendiri, jujur terhadap orang tua, masyarakat, dan jujur terhadap masa depannya. Oleh karenanya, kejujuran para santri sedini mungkin tertanam dalam dirinya baik dalam perilaku, ucapan maupun tanggung jawabnya (Octavia, 2014: 245).

Di samping itu, pendidikan lain yang dilakukan sebagai upaya internalisasi nilai karakter pada santri penderita gangguan jiwa di pesantren Al-Bajigur, menurut Kyai Masturrahman, untuk melihat penderita gangguan jiwa sudah memiliki perkembangan dan masuk pada fase sembuh, maka dapat dilihat pada kesadaran dirinya untuk melakukan shalat berjamaah di mushalla pesantren. Jadi jika sudah memiliki kesadaran spritualitas dalam shalat itulah sebenarnya bentuk karakter religius sudah benar-benar terpatri dalam jiwanya. Karakter religius adalah sikap 


\section{Iwan Kuswandi}

dan perilaku yang patuh dalam melaksanakan ajaran agama yang dianutnya, toleran terhadap pelaksana ibadah agama lain, dan hidup rukun dengan pemeluk agama lain (Narwanti, 2011: 29).

\section{Simpulan}

Setelah dilakukan kajian dan analisa data, dapat disimpulkan: Metode yang digunakan oleh pesantren Al-Bajigur dalam menangani penderita gangguan jiwa, yaitu: Pertama, pasien yang datang akan dilihat dari seberapa ringan dan beratnya gangguan yang ia alami dengan cara diajak berbicara secara persuasif, kedua pasien dimandikan dengan seorang terapis yang menangani, ketiga pasien diminumkan ramuan jamu yang sudah diracik oleh terapis yang akan menaganinya, keempat dikenalkan dengan lingkungan, termasuk tempat dan teman yang sedang menjalani proses reahabilitasi serta mengajarkan untuk bercocok tanam di area sekitar pondok pesantren tersebut, kelima pasien didoakan sebagai hubungan horizontal dengan Tuhan.

Sedangkan pendidikan karakter yang ditanamkan kepada santri penderita gangguan jiwa adalah Pertama, karakter kedisiplinan diri, seperti kedisiplinan dalam memotong kayu, menyapu, dan membantu tukang kuli bangunan, lebih-lebih kedisiplinan dalam hal pelaksanaan shalat fardhu dan mengaji al-Qur'an. Kedua, karakter peduli lingkungan. Kepedulian lingkungan hidup merupakan wujud sikap mental individu yang direfleksikan dalam perilakunya. Ketiga, karakter mandiri, diharapkan mereka nantinya menjadi insan mandiri, bentuk pendidikan yang 


\section{Pendidikan Penderita Gangguan Jiwa di Pesantren dalam Upaya Menjadikan Generasi Bangsa Berkarakter}

diberikan diantaranya ada yang bertani, ada juga yang ikut jadi kuli bangunan, ada juga yang mendapat tugas untuk buat kerajinan tangan. Keempat, karakter tanggung jawab, mengajarkan mereka melakukan pekerjaan tertentu, seperti membersihkan lingkungan pondok dan bercocok tanam, yang tujuannya agar pasien melatih tanggung jawabnya. Kelima, karakter jujur, penanaman nilai-nilai kejujuran menuntut tata kehidupan sosial yang merealisasikan nilai-nilai tersebut. Keenam, karakter religius, kesadaran spritualitas dalam shalat itulah sebenarnya bentuk karakter religius sudah benar-benar terpatri dalam jiwa santri penderita gangguan jiwa.

\section{Daftar Pustaka}

\section{Buku}

Akhmad, Perdana. 2013a. Pro dan Kontra Tidak Mungkin Orang Kerasukan Setan. Jakarta: Qur'anic Media Pustaka.

---,. 2013b. Ruqyah Syar'iyyah VS Ruqyah Gadungan (Syirkiyyah). Jakarta: Quranic Media Pustaka.

--, 2013c. Membongkar Kesesatan Reiki, Tenaga Dalam \& Ilmu Kesaktian. Jakarta: Qur'anic Media Pustaka.

Dzulkarnain, Iskandar, dkk. 2016. Kegilaan Dan Peradaban: Model Penanggulangan Gangguan Jiwa Di Pondok Pesantren Al-Bajigur Sumenep Madura. Prosiding Seminar Nasional Gender \& Budaya Madura III, Madura: Perempuan, Budaya \& Perubahan. Universitas Trunojoyo Bangkalan.

Emoto, Masaru. 2006. The Secret Life of Water. Jakarta: Gramedia.

Narwanti, Sri. 2011. Pendidikan Karakter Pengintegrasian 18 Nilai Dalam Mata Pelajaran. Yogyakarta: Familia.

Octavia, Lanny, dkk. 2014. Pendidikan Karakter Berbasis Tradisi Pesantren. Jakarta: Renebook. 


\section{Iwan Kuswandi}

Tim Fakultas Kedokteran Universitas Hasanuddin Makassar. 2015. Buku Panduan Mahasiswa Tehnik Keterampilan Pemeriksaan Status Mental, Skill Lab. Sistem Neuropsikiatri.

\section{Jurnal}

Adynata. 2013. Penerapan nabi sallallahualaihi Wasallam Ruqyah syariyyah di Klinik Surabaya Ruqyah Center. Jurnal Annida, Volume 38, No 2, Juli-Desember: 7083.

Al-Anwari, Amirul Mukminin. 2014. Strategi Pembentukan Karakter Peduli Lingkungan di Sekolah Adiwiyata Mandiri. Jurnal Ta'dib, Vol. XIX, No. 02, Edisi November: 227-252.

Emosda, Hj. 2011. Penanaman Nilai-nilai Kejujuran dalam Menyiapkan Karakter Bangsa. Jurnal Innovatio, Vol. X, No. 1, Januari-Juni: 151-166.

Hartutik, Sri \& Kanthi Suratih. 2017. Pengaruh Terapi Pijat Refleksi Kaki Terhadap Tekanan Darah Pada Penderita Hipertensi Primer. Jurnal GASTER, Vol. XV No. 2 Agustus: 132-146.

Lutviyanti, Novia Irma. 2013. Internalisasi Pendidikan Karakter dalam Membentuk Kemandirian Anak di Pondok Asih Sesami Kecamatan Baturetno Kapupaten Wonogiri. Sosialitas: Jurnal Ilmiah Pend. Sos Ant, Vol 3 No 2: 1- 14.

Mas'udi, M. Ali. 2015. Peran Pesantren dalam Pembentukan Karakter Bangsa. Jurnal Paradigma, Volume 2, Nomor 1, November: 1-13.

Rahayu, Ratri. 2016. Peningkatan Karakter Tanggung Jawab Siswa SD Melalui Penilaian Produk Pada Pembelajaran Mind Mapping. Jurnal Konseling GUSJIGANG, Vol. 2 No. 1: 97-103.

Rukiyati, dkk. 2014. Penanaman Nilai Karakter Tanggung Jawab dan Kerja Sama Terintegrasi dalam Perkuliahan Ilmu Pendidikan. Jurnal Pendidikan Karakter, Tahun IV, Nomor 2, Juni: 213-224.

Setiawan, Eko. 2015. Nilai-nilai Religius dalam Syair Shalawat Burdah. Jurnal LiNGUA, Vol. 10, No. 1, Juni: 1-8.

Siswanto. 2013. Pendidikan Karakter Berbasis Nilai-Nilai Religius. Jurnal Tadrîs, Volume 8 Nomor 1 Juni: 91-107. 


\section{Pendidikan Penderita Gangguan Jiwa di Pesantren dalam Upaya Menjadikan Generasi Bangsa Berkarakter}

Suhaimi. 2015. Gangguan Jiwa Persepektif Kesahatan Mental Islam. Jurnal Ar-Risalah, Volume 26 No. 4, Desember: 199-200.

Ubaidillah, Aan Fardani. 2016. Pembentukan Karakter Religius dan Mandiri Melalui Model Pendidikan ala Pondok Pesantren. Al-Wijdán: Journal of Islamic Education Studies, Volume I, Nomor 1, November: 1-12.

Wardoyo, Sigit Mangun. 2015. Pendidikan Karakter: Membangun Jatidiri Bangsa Menuju Generasi Emas 2045 yang Religius. Jurnal Tadrîs, Volume 10 Nomor 1 Juni: 90-103.

Yasin, Fatah. 2011. Penumbuhan Kedisiplinan Sebagai Pembentukan Karakter Peserta Didik di Madrasah. Jurnal el-Hikmah Fakultas Tarbiyah UIN Maliki Malang, Vol IX, No 1: 123-138.

\section{Internet}

Ika. 2014. Spidweb Gel, Jaring Laba-laba Percepat Penyembuhan Luka Cabut Gigi. Diakses tanggal 23 Desember 2017. https://ugm.ac.id/id/berita/9191spidweb.gel.jaring.laba-laba.percepat.penyembuhan.luka.cabut.gigi.

\section{Wawancara}

Kyai Abdurrahman (Pengasuh Pesantren Al-Bajigur Tenonan Manding Sumenep), wawancara oleh Iwan Kuswandi, STKIP PGRI Sumenep, tanggal 12 Oktober 2017.

Kyai Masturrahman (Ketua Yayasan Pesantren Al-Bajigur Tenonan Manding Sumenep), wawancara oleh Iwan Kuswandi, STKIP PGRI Sumenep, tanggal 20 Desember 2017. 
Iwan Kuswandi 